\title{
Rediscovery of the Bornean bay cat
}

The bay cat Catopuma badia has been rediscovered in Borneo, where it is endemic and where there have been no confirmed sightings since 1928. In November 1992 an adult female, which had been captured by native trappers on the Sarawak-Indonesian border and kept in captivity for some months, was brought into the Sarawak Museum on the point of death. It was only the seventh known specimen and the first of a whole animal. In appearance it bears a striking resemblance to Temminck's cat $\mathrm{C}$. temminckii, although it is much smaller. Genetic analysis of blood and tissue samples will assist in clarifying its taxonomic status.

\section{Introduction}

The bay cat Catopuma badia (Gray, 1874) is one of the world's least known felids. It is listed in Appendix II of CITES (CITES , 1991), classified as rare in the IUCN Red Data Book (IUCN, 1990), and regarded as endangered by the US Fish and Wildlife Service (1991). Endemic to the island of Borneo, this elusive cat is known from only six specimens, five of which were collected between 1855 and 1900 .

The type specimen was collected by Alfred $R$. Wallace in 1855 , although it was not immediately recognized as a new species. The British Museum acquired the holotype in 1856. The specimen arrived in a poor state of preservation and was initially entered in the register as Felis planiceps?, a flat-headed cat, but qualified with a question mark to signify doubt as to its true identity. It was later assumed to be a juvenile Temminck's or Asian golden cat Catopuma temminckii, but close examination of the skull ruled this out. Having decided that the specimen did represent a new species, J. E. Gray delayed describing the holotype for almost 20 years in hopes of acquiring a more complete example (Gray, 1874).

Later, Jentink (1901) described a bay cat skin held in the Leiden Museum and Pocock (1932) published a description of the three skins in

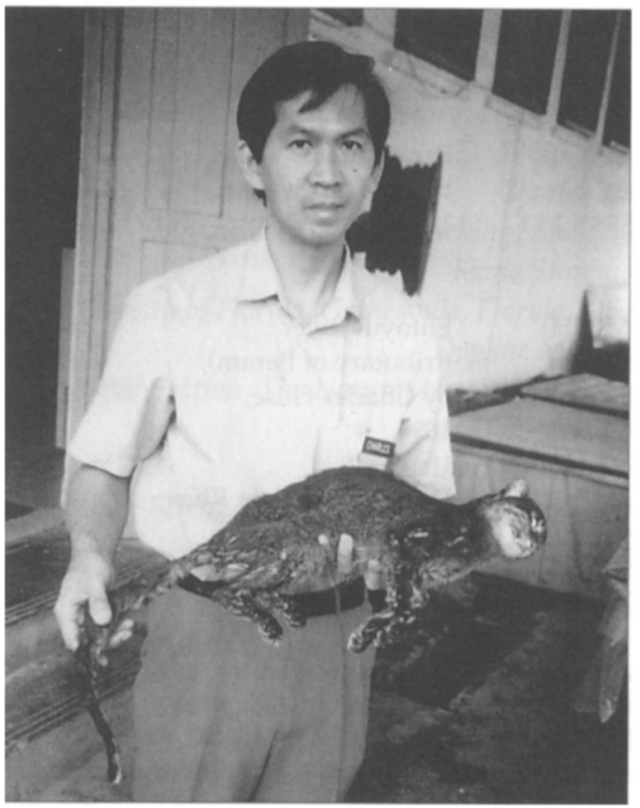

Charles Leh with bay cat (Fiona Sunquist).

the British Museum (Natural History), but there are no photographs or weights and only a few measurements (Table 1). The full extent of our knowledge of this species comes from descriptions of these few skins and their accompanying incomplete skulls.

Nothing is known of the bay cat's biology. Early naturalists reported that this cat was very rare and found only in dense forest (Hose, 1893). At least three of the specimens were collected along rivers, but it is unknown whether this reflects a habitat preference of the bay cat or the collector's most effective method of transport in the rather difficult Bornean terrain.

Since 1928 there have been a few rumours of the cat's continued existence, some unsuccessful searches, and the occasional unconfirmed sighting. In 1986, for example, Birute Galkidas reported seeing a bay cat in her orang utang 
Table 1. Current location, collection sites and measurements of all known bay cat specimens

\begin{tabular}{|c|c|c|c|c|c|c|}
\hline $\begin{array}{l}\text { Current } \\
\text { location of } \\
\text { specimen }\end{array}$ & $\begin{array}{l}\text { Collection site/ } \\
\text { Collector/date }\end{array}$ & $\begin{array}{l}\text { Age/sex/ } \\
\text { colour phase }\end{array}$ & $\begin{array}{l}\text { Head \& } \\
\text { body } \\
(\mathrm{mm})\end{array}$ & $\begin{array}{l}\text { Tail } \\
(\mathrm{mm})\end{array}$ & $\begin{array}{l}\text { Hindfoot } \\
(\mathrm{mm})\end{array}$ & $\begin{array}{l}\text { Ear } \\
(\mathrm{mm})\end{array}$ \\
\hline $\begin{array}{l}\mathrm{BM}(\mathrm{NH})^{*} \\
\text { Reg. No. } \\
1856 . \\
9.19 .16\end{array}$ & $\begin{array}{l}\text { Vicinity of Kuching, } \\
\text { by A. R. Wallace, } \\
\text { c. } 1855\end{array}$ & $\begin{array}{l}\text { Subadult } \\
\text { male } \\
\text { Red phase } \\
\text { (skin in } \\
\text { fragments) }\end{array}$ & & 385 & 115 & \\
\hline $\begin{array}{l}\mathrm{BM}(\mathrm{NH}) \\
\text { Reg. No. } \\
1888.8 .13 .1\end{array}$ & $\begin{array}{l}\text { Baram River, } \\
\text { by A. H. L. Everett, } \\
1888\end{array}$ & $\begin{array}{l}\text { Adult female } \\
\text { Red phase }\end{array}$ & $\begin{array}{l}620 \\
\text { (from } \\
\text { preserved } \\
\text { skin) }\end{array}$ & 380 & 115 & \\
\hline $\begin{array}{l}\mathrm{BM}(\mathrm{NH}) \\
\text { Reg. No. } \\
\text { 1895.5.7.3 }\end{array}$ & $\begin{array}{l}\text { Entoyut River } \\
\text { (tributary of Baram), } \\
\text { by Charles Hose, } \\
1894\end{array}$ & $\begin{array}{l}\text { Adult male } \\
\text { Grey phase }\end{array}$ & $\begin{array}{l}670 \\
\text { (from } \\
\text { preserved } \\
\text { skin) }\end{array}$ & 330 & 135 & 30 \\
\hline $\begin{array}{l}\text { Leiden } \\
\text { Museum } \\
1901 \\
\text { Cat. RMNH }\end{array}$ & $\begin{array}{l}\text { Upper Mahakkan River, } \\
\text { by Dr Nieuwenhuis, } \\
1900 \\
534\end{array}$ & $\begin{array}{l}\text { Adult female } \\
\text { Red phase }\end{array}$ & & 320 & & \\
\hline $\begin{array}{l}\text { Sarawak } \\
\text { Museum } \\
\text { Cat. } 34.41\end{array}$ & $\begin{array}{l}\text { Baram low country, } \\
1891\end{array}$ & $\begin{array}{l}\text { Unknown } \\
\text { Red phase }\end{array}$ & & & & \\
\hline $\begin{array}{l}\text { Sarawak } \\
\text { Museum } \\
\text { Cat. } 34.61\end{array}$ & $\begin{array}{l}\text { Kuching, } \\
1928\end{array}$ & $\begin{array}{l}\text { Juvenile } \\
\text { female }\end{array}$ & 250 & 155 & 112 & \\
\hline $\begin{array}{l}\text { Sarawak } \\
\text { Museum } \\
\text { Cat. } 34.92\end{array}$ & $\begin{array}{l}\text { Sarawak/Indonesia } \\
\text { border, } \\
1992\end{array}$ & $\begin{array}{l}\text { Adult female } \\
\text { Red phase }\end{array}$ & 533 & 391 & 110 & 23 \\
\hline
\end{tabular}

* BM(NH), The Natural History Museum, London.

Pongo pygmaeus study site in Kalimantan (Anon, 1986); however, until now there remain no confirmed reports of the bay cat's existence.

\section{A new specimen of the bay cat}

On 4 November 1992 an adult female bay cat was brought into the Sarawak Museum for deposition in its reference collection (Cat. 34.92). The animal was at the point of death. It was immediately preserved in a freezer. The cat had apparently been caught by native trap- pers on the Sarawak-Indonesia border and held in captivity for some months.

In general appearance the specimen was about the size of a domestic cat with an extremely long tail. It weighed $1.95 \mathrm{~kg}$, but was in a thoroughly emaciated condition with wasted muscles and protruding bones. We estimated that this cat's normal body weight would have been $3.0-4.0 \mathrm{~kg}$.

The cat's coat is dark chestnut-red faintly speckled with black markings. The belly fur is a lighter golden-brown also speckled with black. There is a lighter stripe of yellowish white running down the ventral surface of the 
terminal half of the tail. The backs of the short rounded ears are dark greyish. The top of the head is dark greyish brown with two dark stripes originating from the marginal corner of each eye, and the back of the head has a dark 'M-shaped' marking. The underside of the chin is white and there are two faint brown stripes on the cheeks.

\section{Taxonomic status of the bay cat: past, present, and future}

The limited information suggests that, like Temminck's cat and the jaguarundi Herpailurus jaguarondi, the bay cat is dimorphic in colour. One of the skins in the British Museum represents the grey phase and all the other specimens are of the red phase. Pocock (1932) identified the dimorphic coat colour, dark colour on the backs of the ears and conspicuous white patch on the underside of the tail as suggesting an affinity between the bay cat and Temminck's cat. However, he first classified the bay cat with the marbled cat Pardofelis marmorata, based on the fact that the bay cat's cranial characteristics resembled the marbled cat more closely than the golden cat. Pocock later created a separate genus, Badiofelis, for the bay cat (Hemmer, 1978). Subsequent studies of skull dimensions suggested that the bay cat was simply an island form of Temminck's (Weigel, 1961; Groves, 1982). Most recently, Wozencraft (1993) reclassifed the bay cat and Temminck's cat as the only two species in the genus Catopuma, reverting to the classification of Hemmer (1978) and Groves (1982).

The appearance of this new specimen offers the first opportunity to look at a whole animal and underscores previous suggestions that the bay cat may be an island form of Temminck's cat. While it is much smaller, the new animal is strikingly similar in appearance to Temminck's cat. Temminck's is widely distributed throughout South East Asia, Peninsular Malaysia and Sumatra, but does not occur on Borneo (Lekagul and McNeely, 1977). The bay cat is confined to Borneo, which has been separated from Sumatra and other islands on the Sunda Shelf for $10,000-15,000$ years. This period of isolation is presumably long enough for the bay cat to have become genetically and morphologically distinct. Although the bay cat's taxonomic status is currently unclear, the blood and tissue samples taken for future genetic analysis will help to resolve the taxonomic confusion.

Mel Sunquist

Department of Wildlife and Range Sciences and Florida Museum of Natural History, University of Florida, Gainesville, FL 32611, USA

Charles Leh Sarawak Museum, Kuching, Malaysia Fiona Sunquist

University of Florida, Gainesville, Florida, USA

Daphne M. Hills

Mammal Section, The Natural History Museum, London

Rajanathan Rajaratnam

Senior Scientific Officer, World Wide Fund for Nature, Sabah, Malaysia

\section{Acknowledgments}

We thank Lynette Rajaratnam, Judith Hayter and Junaidi Payne for all their help. We also appreciate the comments of John Eisenberg on the manuscript.

\section{References}

Anon. 1986. Cat News, No. 5, 11.

CITES. 1991. Appendices I, II, and III to The Convention on International Trade in Endangered Species of Wild Fauna and Flora. September, 1991. US Government Printing Office, Washington, DC.

Gray, J.E. 1874. Description of a new species of cat (Felis badia) from Sarawak. Proceedings of the Zoological Society of London, 1874, 322-323.

Groves, C.P. 1982. Cranial and dental characteristics in the systematics of Old World Felidae. Carnivore, 5, 28-39.

Hemmer, H. 1978. The evolutionary systematics of living Felidae: present status and current problems. Carnivore, 1, 71-78.

Hose, C. 1893. A Descriptive Account of the Mammals of Borneo. Edward Abbott, London.

IUCN. 1990. 1990 IUCN Red List of Threatened Animals. IUCN, Gland, Switzerland and Cambridge, UK.

Jentink, F.A. 1901. On Felis badia Gray. Notes from the Leyden Museum, 23, 91-93.

Lekagul, B. and McNeely, J.A. 1977. Mammals of 
Thailand. Association for the Conservation of Wildlife, Bangkok.

Pocock, R.I. 1932. The marbled cat (Pardofelis marmorata) and some other Oriental species, with the definition of a new genus of the Felidae. Proceedings of the Zoological Society of London, 132, 741-766.

US Fish and Wildlife. Service. 1991. Endangered and Threatened Wildlife and Plants. US Government
Printing Office, Washington, DC, 37 pp.

Weigel, I. 1961. Das Fellmuster der wildlebenden Katzenarten und der Hauskatze in Vergleichender und Stammesgeschichtlicher Hinsicht. Säugetierkundliche Mitteilungen, 9, 1-120.

Wozencraft. W.C. 1993. Order Carnivora. In Mammal Species of the World (eds D. E. Wilson and D. M. Reeder), 2nd edn., pp. 279-348. Smithsonian Institution Press, Washington DC.

\section{The decline of the wild water buffalo in north-east India}

The Asiatic wild buffalo Bubalus bubalis was widely distributed in the river systems of south and South East Asia, but habitat destruction, hunting and interbreeding with domestic water buffalo have resulted in only relict wild populations remaining. Unless protection measures are intensified, the species could disappear in India within a few decades.

\section{Introduction and methods}

The bulk of the wild buffalo remaining in India are found in or near the Brahmaputra Valley in the provinces of Assam, Arunachal Pradesh and Meghalaya. The only other area having wild water buffalo is the Indravati National Park and locally elsewhere in the Indravati Valley west of the Madhya Pradesh-Orissa border. It was found over large areas in the Brahmaputra Valley, but it is now restricted to a few localities. Some information on the distribution of the species is given in Gee (1964), Sheshadri (1969) and Grewel et al. (1987, p. 98), but detailed information on distribution and status is lacking. From 1985 to 1993 I was able to carry out field surveys in various parts of north-east India to determine the current distribution and status of the wild buffalo, as part of broader surveys concentrating on primates. As well as travelling widely in Assam, I visited parts of Arunachal Pradesh, Nagaland, Manipur, Mizoram and Meghalaya. In most cases I was able to observe the animals directly, but in

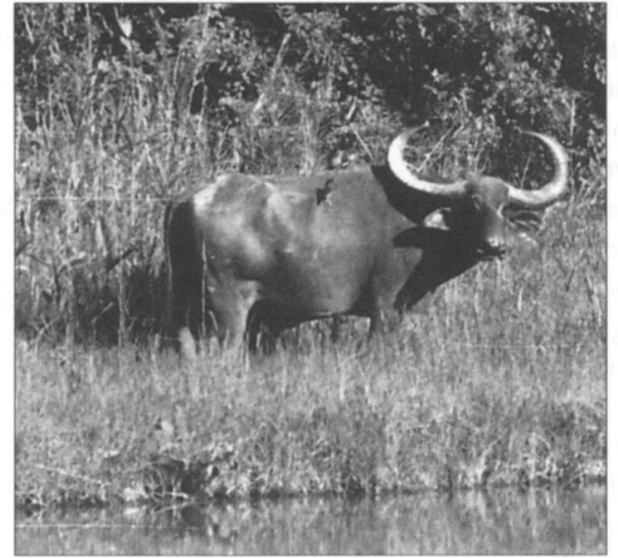

A wild bull buffalo in Dibru-Saikhowa Sanctuary, Assam (A. Choudhury).

some cases I had to rely on interviews with local people and forest officials.

\section{Results}

The current distribution and estimated populations are given in Table 1 and Figure 1. Comments on the data are given below.

Water buffalo favour low-lying wet areas with tall elephant grass, including beels (oxbow lakes and other depressions left by changes in the course of a river), river banks, and chaporis (sandy islets situated between branches of a river in a braided river system). In some instances the populations extend into woodland. The buffalo were active in the daytime only in areas where they are well protect- 